\title{
When the Leader Hits the Wall: A Case of Organizational Paralysis
}

\section{Arthur H. Bell ${ }^{1 *}$ and Dayle M. Smith}

${ }^{1}$ Professor of Management Communication, School of Management, University of San Francisco, USA

${ }^{2}$ Associate Dean, School of Management, Professor of Management, Fulbright Scholar to Hong Kong, 201, University of San Francisco, USA

Like many good ideas and eventual multi-million-dollar companies, "the dot" started out as the hobby of a graduate student, Bob Dessing, earning his Ph.D in Computer Science.

"Look at this," Bob called to his then-girlfriend and later-wife, Sandra. He stuck an adhesive plastic dot, half the size of a dime, onto the recessed bottom of a bottle of wine on their kitchen counter.

"Let me guess," Sandra smiled. "That dot tells me if the wine has a bad cork or has turned to vinegar."

"Better," Bob beamed. He pulled a simple hand-held barcode scanner from his briefcase. A couple protruding wires and assorted solder marks told Sandra immediately that this was no ordinary scanner.

With considerable flourish, Bob swept the scanner past the bottle of wine, about two feet away. He pointed to the letters appearing on the digital readout of the device: "Dry Creek Chardonnay, 2007, purchased $1 / 22 / 2008$ \$16, today's retail \$32."

"So ... "Sandra stroked her cheek. "What, we can now get a daily reading on the value of our four bottles of wine? Bob, how much time have you spent on this?"

Bob laughed. "You're missing the big picture," he said. "Put a plastic dot like this on the bottom of every bottle of wine you bring into a big restaurant, let's say, and you can inventory your entire wine cellar in a matter of minutes. You can pick out the bottle you're looking for without a lot of hunting and picking. Best of all, you can figure out your retail sales price right away this thing (Bob waved the scanner in the air) interfaces wirelessly with a real-time American Vintner's data base of retail wine prices."

Sandra looked more reflectively at the device. "Let me hold it," she said. "Does it just read what's on the plastic dot, or can it encode the dot as well?"

"You're brilliant," Bob exclaimed, "but this time I'm a step ahead of you. Watch this." He deftly tapped a few keys on the scanner, aimed it at the dot on the bottle of wine, and pulled the trigger. "Voila!" he said. "We now have a Rothschild Cabernet, 1992, \$210."

"Very cool," Sandra replied. "You just code in whatever bottle you bring into inventory, and from that moment on you have a complete record of what is it, how much you paid for it, and about how much you should charge to your customer. How many individual records can you hold in that thing?"

"Well, tonight about ten. But tomorrow I'm loading it up with an 8 -gig card, at which point it will hold about 50,000 bottles in memory, with wireless backup to a remote hard drive."

"Good God," Sandra exclaimed in jest. "Where are we going to put 50,000 bottles of wine? And, by the way, was that 8-gig card the $\$ 89$ charge that showed up on our VISA bill yesterday?"

"An investment!" Bob protested. "This could be the beginning of something really big."
"Big with all the wine barons you know?" Sandra teased. She knew that Bob couldn't tell a Merlot from Chianti and could care less.

"Build it and they will come," Bob grinned. "You are observing the birth of the Dessing Dot."

Flash forward twenty-four months. Bob, now a newly-minted Ph.D, has just landed his first job as an assistant professor at U.C. Berkeley. $\mathrm{He}$ and Sandra have married and are trying to make ends meet in the expensive housing environment of the Bay Area. The Dessing Dot, while not entirely ignored, has not yet brought fame and fortune. Bob has managed to gain a trademark on the name itself, and has a patent pending for both the dot and the scanner, including the software that animates them.

Negotiating successfully for $\$ 400$ in their meager savings (the $\$ 400$ that Sandra had ear-marked for a decent living room chair), Bob rented a booth toward the back of Row W at the massive Northern California Wine Show at San Francisco's cavernous Moscone Center. Compared to other exhibitors, his display was humble indeed: twenty empty bottles of wine laid on their side, each bearing a Dessing Dot. A sign above the booth bluntly proclaimed, "The Dessing Dot-Revolutionize Your Cellar."

Especially because he had nothing to give passersby to taste or tuck away in their bags of manufacturer freebies, Bob sat for more than three hours without so much as a single conversation with anyone. Then, at 11:37 am (as both of them remembered later), lightning struck. Teresa Marshall walked briskly past his booth, stopped, and (for reasons she herself couldn't explain later) asked Bob, "So what's the Dessing Dot?"

Bob gave his first but well-rehearsed demo to Sandra, showing how a wide variety of data could be encoded via the Dessing Dot on each bottle, retrieved by the scanner, updated wirelessly, and stored remotely. He could visibly watch Teresa's jaw drop.

"I'm sorry," Bob concluded. "I didn't catch your name."

"Teresa," she mumbled. "Teresa Marshall. I'm vice president of retail sales at Marshall Winery in Napa Valley." She handed him an expensive-looking and impressive business card.

"You're a big winery?" Bob asked naively.

Teresa smiled. "Well, there's Gallo," she said, "and the Mondavi brothers. And then us."

*Corresponding author: Arthur H. Bell, Professor of Management Communication, School of Management, University of San Francisco, USA, E-mail: bell@usfca.edu

Received June 26, 2012; Accepted June 27, 2012; Published June 29, 2012

Citation: Bell AH, Smith DM (2012) When the Leader Hits the Wall: A Case of Organizational Paralysis. J Entrepren Organiz Manag 1:e101. doi:10.4172/ 2169-026X.1000e101

Copyright: (c) 2012 Bell AH, et al. This is an open-access article distributed under the terms of the Creative Commons Attribution License, which permits unrestricted use, distribution, and reproduction in any medium, provided the original author and source are credited. 
"Oh," Bob half-whispered. "You are big."

"Yes," Teresa smiled. "And you have an incredible device here. Want to sell it?"

Bob was taken aback. He had come prepared to sell one of his kits (a scanner and twenty dots) for $\$ 89.00$. "Sell you a scanner and some dots?" he asked weakly.

"No, no," she laughed. "I mean the whole thing-do you want to sell me complete rights to this ... this Dessing thing?"

Bob wisely hesitated. "I need to talk to my business partner," he said, already thinking ahead to an exciting conversation with his only partner, his wife.

"Fine," Teresa said. "But do me this favor. Don't commit to anyone else for 48 hours until we have had a chance to meet again and talk, OK?"

"Yes ... yes, that's great," Bob agreed. "Do you want it in writing or something?"

Teresa looked at him shrewdly. "You look like the kind of person who keeps his word."

"True," Bob said. "We'll talk in the next couple days."

Flash forward another six months. Bob, in spite of Teresa's eventual offer of more than $\$ 1$ million, has decided to retain ownership rights to his unique device. Teresa, his ultimate true believer in the future of the Dessing Dot, has taken a one-year sabbatical from Marshall Winery to head a start-up, Dessing Wine Technologies, with herself as president and Bob and Sandra as founders, owners, and majority stockholders. Teresa has agreed to take most of her salary in stock options. Bob and Sandra could not be more pleased. Bob and Sandra found no particular joy in direct sales, heavy travel schedules, or bare-knuckles negotiations. At this point, they had a baby on the way and Bob had the long road to academic tenure to think about. They were content to let Teresa run with the Dessing Dot and to cheer her on in monthly meetings.

Run with it she did. Resolving not to give away half the company or more to the "hard money" market of venture capitalists, Teresa arranged first-round "angel" funding of $\$ 1.5$ million from her parents at Marshall Winery, a loan secured by not much more than her stock options and her enthusiasm. Bob's patent had come through for all aspects of the Dessing operation, so Teresa was able to proceed quickly to a manufacturing contract with a reliable Chinese electronics factory. Within two months, the first run of 5000 tested and packaged Dessing Dot units were safely stored in a rented South San Francisco warehouse, part of which doubled as a showroom for the product and general office space for operations.

Teresa had accomplished everything except to bring customers to the company. "It will sell itself," Teresa had told Bob and Sandra more than once. "We just have to get face time with upscale restaurant owners."

"We," of course, did not mean Teresa personally, nor of course did it involve Bob and Sandra. Teresa needed salespeople. She had little luck attracting actual wine sales people from her extensive network. They were all making a good living, loved wine itself more than technology, and didn't foresee the same commissions from selling dots instead of cases of fine wine.

Her experience in attracting "techie" salespeople was no more successful. Through a series of Help Wanted ads in San Francisco magazines, newspapers, and on-line sources, she managed to bring 25 potential salespeople into a large meeting room at a well-known San Francisco hotel. She talked to them through the technology itself, which they "got" quickly. But they obviously had no feel for wine, restaurateurs, sommeliers, or wine stewards. She finally selected six from the group as her inaugural sales force and resolved to follow each at least once every two weeks or so on as one of their sales calls.

She quickly came to dread these ride-along experiences. Restaurants are hectic places, and the higher you are in the restaurant's hierarchy, the more frenetic your typical day. Simply getting ten minutes of time with a real decision-maker within the restaurant proved difficult. Appointments were shuffled off to head waiters or hostesses, most of whom just played along with the sales call, knowing they had no authority to buy anything.

Teresa's techie salespeople didn't encourage better, higher-level relationships. They talked endlessly about the "ground-breaking technology" involved in the Dessing Dot and the required wireless standards for accurate transmission of data. These lectures brought many more yawns than sales from potential customers. Knowing the wine industry intimately, Teresa tried to use her smarts and family name to salvage these sales calls, but with limited success. At best, she got "courtesy" treatment from restaurateurs who knew her mother and father.

After seven months, Teresa had spent the first million dollars of her $\$ 1.5$ million angel loan. She doubted that her parents would lend her more, not because they doubted the potential for the Dessing product but because she seemed to have no plan for overcoming the very real obstacles posed by customers used to doing business and handling their wine in traditional ways. "Why would I need stick-on dots?" one sommelier asked her. "Our wines are meticulously catalogued by row and column, and entered in a registry as soon as they arrive at our cellar. Name any wine on our wine list and I can hand it to you within five minutes." Another restaurateur objected to electronics generally: "Our customers don't want to see an electronic scanner anywhere near their chosen bottle of wine, and some will have a very negative reaction to any electronic chips stuck on the bottom of the bottles." Teresa tried to counter these objections with all the benefits and advantages of the Dessing system, but seldom to any avail.

At a memorable meeting with Bob and Sandra (and their financial advisor, who had informally joined the company at this point), Teresa vented her frustration after eight months of her year-long commitment as company president. "It's like we have the first printing press," she said, "but the world doesn't want to read. I'm at my wits end trying to get the real players in the wine industry to give my people even a few minutes of their time. And the sales people themselves are limping along at best. We've had to give them a base salary against future commissions, but at this rate I don't know if any of them will come close to the sales targets we projected. They all know technology, but they don't know wines-and when they try to fake it, the sommeliers and wine stewards spot it right away and write them off as newbies or worse."

Bob didn't know what to say. He was up to his ears in his own "publish or perish" activities in an effort to eventually get tenure. Sandra felt Teresa's pain, but didn't have any answers. Hiring new salespeople didn't seem practical; just training the first group had taken an enormous amount of Teresa's executive time and energy. Bob and Sandra, as their accountant often reminded them, had not seen a dime of income from their fledgling company. Privately, Bob had expressed 
to Sandra his misgivings: "Maybe I should have sold out when Teresa offered \$1 million for the whole thing. I doubt that anyone would offer us anything near that, now that we've pretty much proven that very few people want to buy want we have to sell." Bob and Sandra weren't personally "on the hook" to repay the $\$ 1.5$ million invested by Teresa's parents, but they knew that Teresa took this obligation very seriously and could potentially lose whatever financial nest-egg and organizational power she had built up within the Marshall organization. It was a distinct possibility that within four months, Teresa could be leaving the company empty-handed and heavily in debt to her parents, while Bob and Sandra were back where they started-playing with a clever device that did quite amazing things, but couldn't seem to find its market.

Well after midnight following this meeting, Teresa flipped out her iPad and began to jot basic questions:

1. Should we be trying to sell our product right now or just placing it for free in high-visibility restaurants and wine bars?

2. Are we wasting our money on a half-baked sales crew, even if they are trying their best? Would that money be better spent on some really classy ads in wine and food magazines?

3. We've got $\$ 500,000$ left and most of our original inventory. What's the best way to use both of them in the next four months before my sabbatical from Marshall ends and I have to decide whether to go back there or to continue with Bob and Sandra?

4. How do we get some kind of huge exposure, like the Home Shopping Network or the Food Channel? I've seen other people doing demonstrations on those programs that are stupid compared to what we have.

5. What am I doing wrong as a leader? I'm putting in 16-hour days, Bob and Sandra trust me, and I'm working my butt off trying to hire sales people, teach them the product, and then hand-hold them as they try to sell it. It's been the most discouraging eight months of my life! All I have to show for it is a lot of debt to my parents and total exhaustion.

6. And what's our plan from here on? I'm president and I don't have a clue, except to put on a smile every morning and try to keep our sales people motivated to keep banging their heads against the wall of hardly any sales.

7. Bob said maybe we should hire a consultant. What's that all about? If he thinks he is going to find someone who knows the wine industry better than I do, he's kidding himself. We'll end up paying thousands to some consultant who will leave us holding a couple videotapes, some workshop handouts, and a receipt for his services.

\section{REWIND: Four Areas for Discussion and Analysis}

Assume that Bob's invention is the "real thing" and can, in fact, produce all the benefits he, Sandra, and Teresa claim it can for the management of large wine inventories in restaurants and wine bars. Obviously something has gone expensively awry in what could have been a bright future for Dessing Wine Technologies.

The challenge for an upper-level undergraduate or MBA class in Entrepreneurship and/or Organizational Management is to identify issues and potential solutions that could have set this venture on a much more successful course.

\section{Approach to marketing and sales: Evaluate Teresa's approach in}

these areas. Did she choose the right mix of sales channels to reach potential buyers? Was she premature in assembling an actual sales force to call on likely clients? Did she correctly define the kind of salesperson her young company needs? By what means did she attempt to motivate her sales team? Assess the relative success or failure of her approach to motivation in the areas of sales and marketing.

2. Financial management: Did Teresa make good strategic choices in her use of the company's "angel" funding? Develop a set of options that she could have considered in deciding how to structure and allocate the company's finances.

3. Leadership: As Bob Dessing quickly realized, Teresa had many of the qualities ordinarily associated with a superb leader: expert knowledge, passion for her job, an excellent work ethic, good industry connections, and highly developed communication skills. Yet she found herself failing in many ways as a leader. Assess factors that led to her leadership problems. Include in this analysis her relationship with the original founders of the company. Did she use their talents to best advantage in her efforts to develop the young company? What principles of entrepreneurship did she follow or fail to follow, and with what result? Did she delegate too much or too little? Analyze her approach to building an initial team for the company. What business resources did she use or fail to use to support her leadership efforts?

4. Company organization: Study the organizational structure established by Teresa and the Dessings. Given the problems experienced by the company, should the company have been structured differently? In what ways and why? 